\author{
Tomasz Spórna \\ https://orcid.org/0000-0002-1099-7196 \\ Uniwersytet Śląski w Katowicach \\ Wydział Nauk Przyrodniczych, Sosnowiec \\ Instytut Geografii Społeczno-Ekonomicznej i Gospodarki Przestrzennej \\ tomasz.sporna@us.edu.pl
}

\title{
PROCES SUBURBANIZACJI W STREFIE ZEWNĘTRZNEJ KONURBACJI KATOWICKIEJ - PRZYKŁAD SŁAWKOWA
}

\begin{abstract}
Abstrakt: W artykule przedstawiono zmiany przestrzenne i demograficzne w strefie zewnętrznej konurbacji katowickiej na przykładzie małego miasta Sławków. W szczególności zostały scharakteryzowane zmiany zachodzące na terenie miasta po 1990 r. w zakresie indywidualnego budownictwa mieszkaniowego. Nowe strefy zabudowy domów jednorodzinnych zostały zdefiniowane jako obszary podlegające procesom suburbanizacji rezydencjonalnej (w granicach administracyjnych miasta, tzw. suburbanizacja "wewnętrzna”. Ich rozmieszczenie odznacza się specyficzną fizjonomią oraz „wyspową” lokalizacją w policentrycznym regionie miejskim.
\end{abstract}

Słowa kluczowe: nowa zabudowa mieszkaniowa, suburbanizacja, małe miasto, Sławków, konurbacja katowicka.

\section{SUBURBANISATION PROCESS IN OUTER ZONE OF KATOWICE CONURBATION \\ - AN EXAMPLE OF SŁAWKÓW}

\begin{abstract}
The article presents spatial and demographic changes in the external zone of the Katowice conurbation - on the example of a small town Sławków. In particular spatial changes of the distribution of new single-family houses occurring in the city after 1990 were characterized. Newly built zones of single-family houses development have been defined as areas subject to residential suburbanization processes (within the city's administrative boundaries, 'inner' suburbanisation). Their arrangement is characterized by specific physiognomy and an 'island' location in the polycentric urban region.

Keywords: new housing estates, suburbanisation, small city, Sławków, Katowice conurbation.
\end{abstract}

\section{WPROWADZENIE}

Nowe podstawy rozwoju gospodarczego i zmiany społeczne, wywołane transformacją ustrojowo-gospodarczą krajów Europy Środkowo-Wschodniej, przyczynily się do dynamicznie zachodzących procesów dekoncentracji przestrzennej miast (Schmidt, Fina, Siedentop, 2015; Stanilov, Sýkora, 2014). Jak stwierdzili Kurek, Wójtowicz i Gałka (2020) proces ten dotyczy większości miast Polski i ich stref podmiejskich. Autorzy licznych prac wskazują, że proces ten jest spowodowany głównie czynnikami społeczno-ekonomicznymi, administracyjnymi, uwarunkowaniami związanymi z planowaniem przestrzennym na poziomie gminnym, czynnikami środowiskowymi, obecnymi warunkami mieszkaniowymi oraz modą na zamieszkanie poza miastem (Kajdanek, 2012; Mantey, 2011; Zborowski, Raźniak, 2013).
Szczególnym przypadkiem jest proces suburbanizacji rezydencjonalnej, przejawiający się rozwojem obszarów o zabudowie jednorodzinnej (indywidualnej lub deweloperskiej) ${ }^{2}$ na obszarach podmiejskich nie tylko dużych, ale także średnich i małych miast. Na zjawisko to zwróciła szczególną uwagę Kajdanek (2012).

Na terenie Polski procesowi dekoncentracji przestrzennej podlega większość aglomeracji miejskich (Śleszyński, 2006). Wyjątkiem w tym procesie, jednak wyłącznie w ujęciu statystycznym, jest konurbacja katowicka. Na jej obszarze jest obserwowany ubytek demograficzny w strefie rdzeniowej i zewnętrznej (Krzysztofik, Kantor-Pietraga, Runge, Spórna, 2017). Zjawisko redystrybucji ludności w tym policentrycznym regionie miejskim, występowanie na jego obszarze stref wzrostu i ubytku ludności 
(w ujęciu wewnątrzmiejskim) jest bardzo zróżnicowane (Spórna, 2018). Przejawia się to zróżnicowanym umiejscowieniem i formą procesu suburbanizacji rezydencjonalnej. $W$ tym kontekście ważna jest $\mathrm{w}$ badaniach m.in.:

- identyfikacja i rozmieszczenie stref nowych inwestycji mieszkaniowych oraz zmian zaludnienia $\mathrm{w}$ regionie miejskim objętym procesem depopulacji;

- odpowiedź na pytanie, jakie czynniki/procesy są odpowiedzialne za ich wystąpienie.

W przypadku największego układu osadniczego Polski, jakim jest konurbacja katowicka, odpowiedzią na pytanie o przyczyny zróżnicowania zachodzących procesów demograficznych (oprócz transformacji społeczno-gospodarczej), może być sama jego struktura przestrzenno-funkcjonalna. Ma ona charakter policentryczny, sprzyjający powstawaniu stref nowej zabudowy mieszkaniowej o rozmieszczeniu „punktowym” lub „wyspowym”. Nowo powstałą jednorodzinną i wielorodzinną zabudowę mieszkaniową można postrzegać w kontekście procesu suburbanizacji i reurbanizacji, którą Klasik (2019) definiuje jako przykład „,nowej urbanizacji na starym podłożu". Jej szczególnym przykładem są liczne domy jednorodzinne (indywidualne lub deweloperskie) lokalizowane na terenach niezagospodarowanych $\mathrm{w}$ granicach miast konurbacji (pomiędzy wiloośrodkowo rozmieszczonymi strefami już zabudowanymi) oraz na obszarach sąsiadujących z nimi gmin wiejskich. W tym przypadku mamy do czynienia przede wszystkim z procesem suburbanizacji, występującym zarówno $\mathrm{w}$ granicach miast, jak i w tradycyjnie pojmowanej strefie podmiejskiej (poza granicami miasta) (por. Lisowski, Grochowski, 2008; Lorens, 2005).

Jednym z przykładów takiego punktowego, wieloośrodkowego rozwoju zabudowy jednorodzinnej w konurbacji katowickiej jest Sławków. Na jego obszarze w otoczeniu zieleni dynamicznie rozwijała się indywidualna zabudowa jednorodzinna. Jest to specyficzny przykład suburbanizacji, gdzie systematycznie miała miejsce sukcesja roślinna (rozwój lasu sosnowego). Można zatem wysunąć tezę, że $\mathrm{w}$ tym przypadku mamy do czynienia $\mathrm{z}$ rozwojem osadnictwa na tzw. surowym korzeniu, a powstałe tam w latach 1990-2018 domy były budowane na nieużytkach porolniczych lub terenach sukcesji leśnej. Ta specyfika rozwoju urbanizacyjnego małego miasta (Sławkowa) w otoczeniu rdzenia konurbacji katowickiej była bezpośrednią przyczyną podjęcia badań.

Przeprowadzone na użytek niniejszego artykułu badania pozwoliły na udzielenie odpowiedzi na następujące pytania badawcze: 1 . Czy rozwój nowej zabudowy indywidualnej na obszarze małego miasta nosi znamiona procesu suburbanizacji? 2. Jakie są główne czynniki stymulujące rozwój tego procesu?, oraz 3. Czy proces ten ma charakter planowy czy spontaniczny?

\section{MAŁE MIASTA W OTOCZENIU DUŻYCH OŚRODKÓW MIEJSKICH I PROCESY SUBURBANIZACJI W POLSCE}

Szczególna intensyfikacja studiów nad małymi miastami w Polsce miała miejsce w latach 50. i 60. $X X$ w. Była ona związana $z$ ich odbudową, przekształceniami układów urbanistycznych oraz dalszym rozwojem (Dziewoński, Kiełczewska-Zaleska, Kosiński, Kostrowicki, Leszczycki, 1957). W wyniku industrializacji i kontynuacji rozwoju urbanizacyjnego kraju badania zostały ukierunkowane na miasta średnie i duże. Po 1989 r. odnotowujemy ponowny wzrost zainteresowania strukturą przestrzenno-funkcjonalną oraz rolą małych miast w strukturze osadniczej kraju bądź regionu (Kwiatek-Sołtys, 2011; Szymańska, Grzelak-Kostulska, 2005), a w szczególności po 2000 r. (Heffner, 2008; Heffner, Marszal, 2005, 2007, 2011; Jażdżewska, 2009; Korzeniak, 2014).

$\mathrm{W}$ drugiej połowie lat $90 . \mathrm{XX} \mathrm{w}$. badania zostały skierowane na rozwój gospodarczy i przestrzenny małych miast, w szczególności w kontekście wpływu na ich rozwój sąsiadujących z nimi dużych ośrodków miejskich. Rozwój małych miast położonych w strefie podmiejskiej dużych miast był głównie podyktowany zachodzącymi na ich obszarach procesami suburbanizacji rezydencjonalnej i suburbanizacji przemysłowo-usługowej (firm). Przykłady takich przekształceń zachodzących w XXI w. zostały przedstawione $w$ licznych pracach empirycznych. Warto tutaj wymienić chociażby studia dotyczące małych miast, m.in. z aglomeracji: gdańskiej (Jażewicz, 2008), krakowskiej (Gołąb-Korzeniowska, 2008), poznańskiej (Konecka-Szydłowska, Matykowski, 2005; Świdurska, 2008), łódzkiej (Milewska-Osiecka, 2016; Ogrodowczyk, 2011), czy też konurbacji katowickiej (Zuzańska-Żyśko, 2007; Polko, 2010). Prace te wyraźnie dowodzą, że bliskie sąsiedztwo z dużym ośrodkiem miejskim oddziałuje na rozwój przestrzenny małych miast i wpływa m.in. na wzrost znaczenia jego funkcji mieszkaniowej. W wielu przypadkach takiego rozwoju mamy do czynienia z procesem suburbanizacji rezydencjonalnej, który 
może być rozpatrywany $\mathrm{w}$ dwóch perspektywach badawczych: 1) migracji, utożsamianej ze zmianami w układzie regionalnym, oraz 2) w kontekście cyklu życiowego miast (Zborowski, Raźniak, 2013).

Kajdanek (2012) zwraca uwagę, że „współczesne osiedla podmiejskie powstają nie tylko wokół wielkich, ale także w sąsiedztwie średnich i małych miast w Polsce" (ibidem, s. 9). Zjawisko to można zaobserwować np. w otoczeniu małych miast w województwie dolnośląskim. Zostało ono udokumentowane m.in. na terenach wiejskich gmin miejsko-wiejskich: Syców, Stronie Śląskie (Kajdanek, 2012) i Oborniki Śląskie (Maleszka, Kazak, Szewrański, 2016). W większości miejskich obszarów funkcjonalnych, podlegających dynamicznemu procesowi wzrostu zaludniania, zjawisko suburbanizacji występuje także $w$ małych miastach oraz $w$ ich bezpośrednim otoczeniu (Śleszyński, 2006; Kurek, Wójtowicz, Gałka, 2020).

Studia nad przekształceniami funkcjonalnymi małych miast $\mathrm{w}$ województwie śląskim podjęła m.in. Zuzańska-Żyśko (2006), a strukturę użytkowania ziemi małych ośrodków miejskich otaczających rdzeń konurbacji katowickiej scharakteryzował Gibas (2011). Jego badania dowodzą, że Sławków na tle innych małych miast otoczenia konurbacji katowickiej zajmuje trzecią pozycję pod względem udziału terenów przeznaczonych pod zabudowę zurbanizowaną (z blisko $29 \%$ ).

$\mathrm{W}$ odniesieniu do badań $\mathrm{w}$ małych miastach $\mathrm{w}$ otoczeniu konurbacji katowickiej $\mathrm{w}$ aspekcie przestrzennym powinno się wspomnieć także prace podejmujące tematykę: krajobrazową (Zuzańska-Żyśko, 2001), funkcji mieszkaniowej w strefie oddziaływania ośrodków rdzenia konurbacji (Polko, 2010), czy też udziału małych miast w strukturze aglomeracji miejskich, $\mathrm{w}$ tym $\mathrm{w}$ układach policentrycznych (Szaton, 2016; Zuzańska-Żyśko, 2007).

\section{OBSZAR BADAŃ}

Sławków to małe miasto, zajmujące powierzchnię $37 \mathrm{~km}^{2}$ i liczące w 2018 r. 7 tys. mieszkańców. Miasto o średniowiecznym rodowodzie, które uzyskało prawa miejskie w XIII w. (Kiryk, 2001). Powstało na historycznym szlaku handlowym z Krakowa do Bytomia, w rejonie którego wydobywano srebro, cynk i ołów. Liczne wzloty i upadki znaczenia miasta spowodowały utratę przez nie w $1870 \mathrm{r}$. praw miejskich. Dynamiczny rozwój Sławkowa, oprócz XIII i XIV stulecia, przypadł później na lata 70. XX w.
To wtedy ówczesna gromada Sławków została włączona w granice administracyjne Dąbrowy Górniczej, a na jej obszarze powstały zakłady transportu kolejowego ród żelaza dla pobliskiej Huty Katowice i Koksowni Przyjaźń (Orłowski, 2001). Budowa magistrali kolejowej (Linia Hutniczo-Siarkowa LHS3), łączącej Sławków z Krzywym Rogiem na Ukrainie (złoża rud żelaza), przyczyniła się do izolacji przestrzenno-funkcjonalnej miasta od jego strony południowej. Obszary południowego Sławkowa do początku lat 90 . XX w. pozostawały słabo zaludnione, a problemy gospodarcze kraju w latach $80 . \mathrm{XX}$ w. zbiegły się z niezadowoleniem społecznym mieszkańców miasta, czego skutkiem było odzyskanie przez nie w 1984 r. praw miejskich (Matuszczyk, 2016). Na początku XXI w. podjęto próbę rewitalizacji przestrzeni miasta (Adamczyk, 2011a) oraz dostrzeżono szanse gospodarcze miasta, w szczególności w kontekście jego lokalizacji na pograniczu dwóch województw: śląskiego i małopolskiego (Adamczyk, 2011b).

Sławków jest połżony nad Białą Przemszą w powiecie będzińskim, w strefie otaczającej miasta rdzenia konurbacji katowickiej. Przez miasto przebiega równoleżnikowo droga krajowa nr 94, która łączy m.in. Bytom, Sosnowiec, Dąbrowę Górniczą i Olkusz z Krakowem. Sławków graniczy z pięcioma gminami (z których cztery są miastami): od zachodu z Sosnowcem, od północnego zachodu z Dąbrową Górniczą, od wschodu z gminą wiejską Bolesław, od południowego wschodu z Bukownem oraz od południa z Jaworznem (rys. 1).

Położenie miasta w strefie otaczającej duże ośrodki miejskie (strefie podmiejskiej) pozwala na obserwowanie jednych z ciekawszych przemian struktury przestrzenno-funkcjonalnej małych miast konurbacji katowickiej, a mianowicie kształtowania się stref nowej zabudowy mieszkaniowej w otoczeniu historycznego śródmieścia miasta (na południe i południowy zachód od niego). Sławkowskie nowe osiedla mieszkaniowe indywidualnej zabudowy jednorodzinnej (z lat 1990-2018) stanowią wyjątkowy przykład procesu suburbanizacji w skali całej konurbacji katowickiej. Przede wszystkim dlatego, że są zlokalizowane na obszarach typu greenfields - łąkach śródleśnych oraz terenach podlegających sukcesji roślinności (głównie drzew iglastych). Koncentrują się one w czterech strefach "nowej” suburbanizacji, w otoczeniu zieleni. Tworząca się tutaj sieć ulic swoimi nazwami podkreśla przyrodniczy charakter tych stref; są to m.in. ulice: Borowa, Brzozowa, Konarowa, Jaśminowa, Stokrotek. 


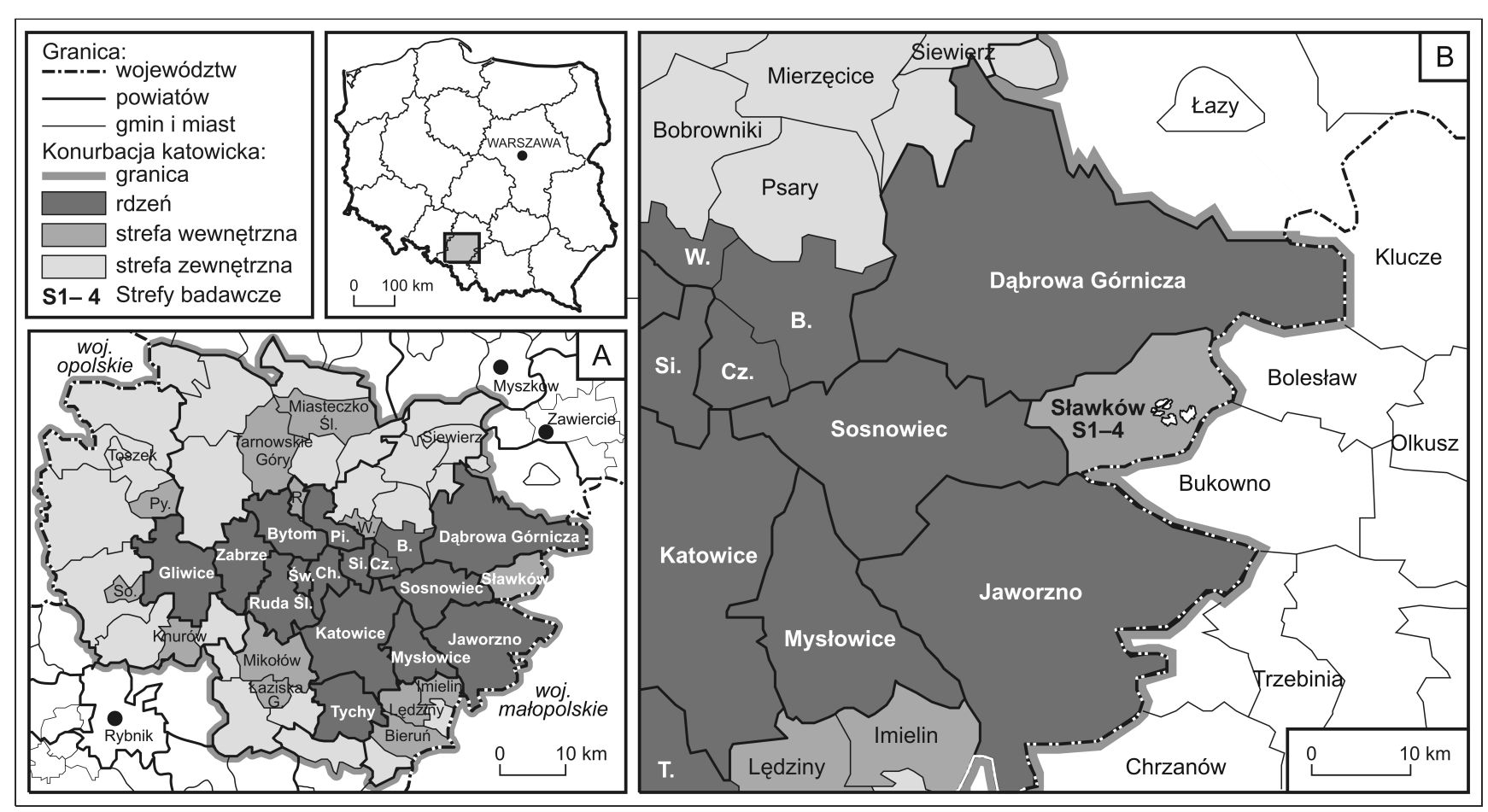

Rys. 1. Obszar badań - miasto Sławków na tle konurbacji katowickiej Źródło: opracowanie własne na podstawie delimitacji Krzysztofika (2007)

Atrakcyjne położenie Sławkowa, w tym liczne tereny zielone, ale także polityka przestrzenna władz miejskich, przyczynily się do powstania stref suburbialnych na południowy zachód od śródmieścia miasta, na obszarach niezagospodarowanych (łąki śródleśne, las). Są to: strefa 1. będąca częścią osiedla Korzeniec (ulice Korzenna oraz Jaworowa/ Borowa), strefa 2. - Stawki (ul. Stawki), strefa 3. - rejon ulic Jaśminowej i Stokrotek, oraz strefa 4. - rejon ul. Krakowskiej (rys. 1B). Łącznie powierzchnia wymienionych stref obejmowała $0,59 \mathrm{~km}^{2}$, z zaludnieniem wynoszącym w 2014 r. 463 osoby.

\section{4. ŹRÓDŁA DANYCH I METODY BADAWCZE}

W pracy $\mathrm{w}$ celu realizacji zamierzeń badawczych wykorzystano następujące źródła danych:

1) statystyczne: dane ludnościowe za lata 19902018 pozyskane z Banku Danych Lokalnych GUS, Bazy Demograficznej GUS, Roczników statystycznych województwa katowickiego (za lata 1992-1995) i bazy PESEL (dane podlegały procesowi geokodowania);

2) kartograficzne: Mapa topograficzna... (1992), Baza Danych Obiektów Topograficznych (BDOT
$10 \mathrm{~K}, 2013)$ oraz ortofotomapy z portalu geoportal. gov.pl (Ortofotomapa, 2017), geoportal miasta Sławków (geoportal.slawkow.pl) oraz Otwarty Regionalny System Informacji Przestrzennej Województwa Ślaskiego (orsip.pl).

3) dokumenty planistyczne i strategiczne miasta Sławków, takie jak: Strategia rozwoju... (2015), Studium uwarunkowań... (1998, 2003, 2008, 2011, 2019), Miejscowy plan zagospodarowania... (2006 ze zm.);

4) komercyjne: strony internetowe oferujące możliwość kupna/sprzedaży działki budowlanej/ domu (otodom.pl) oraz portale umożliwiające obliczenie odległości drogowej oraz czas dojazdu z gmin otaczających Sławków do jego centrum (targeo.pl).

Uzupełnieniem wymienionych źródeł danych były badania terenowe pozwalające określić zmiany przestrzenne oraz motywy zamieszkania ludności w badanych strefach.

Wśród metod badawczych zastosowano m.in. inwentaryzację urbanistyczną nowo powstałej zabudowy mieszkaniowej, prowadzoną na przełomie czerwca i lipca 2016 r. oraz w lipcu 2018 r. W celu zbadania motywów zamieszkania ludności w sławkowskich strefach suburbialnych oraz określenia ich charakterystyki społeczno-demograficznej przeprowadzono w czerwcu 2017 r. 20 wywiadów pogłębionych z przedstawicielami nowych gospo- 
darstw domowych (z domów jednorodzinnych wybudowanych po 1990 r.). Gospodarstwa domowe biorące udział $\mathrm{w}$ badaniu zostały wybrane losowo. Stanowią one 10,5\% nowych gospodarstw domowych w badanych czterech strefach Slawkowa.

Do interpretacji zebranych danych posłużono się metodami geostatystycznymi oraz metodami opisu statystycznego (m.in. wykres pudełkowy). W celu opracowania wyników badań wykorzystano oprogramowanie statystyczne (SPSS, MS Excel) oraz narzędzia geoinformacyjne (Mapinfo i QGIS).

\subsection{ZMIANY OSADNICZE W SŁAWKOWIE JAKO PRZEJAW PROCESU SUBURBANIZACJI}

Od początku lat 90. XX w. rozwój osadniczy Sławkowa ukierunkowany był na zagospodarowywanie atrakcyjnych przyrodnio terenów położonych na południowy zachód od jego historycznego centrum.
Było to związane z polityką przestrzenno-planistyczną władz miejskich, skupioną na wydzieleniu stref „nowej urbanizacji” i ich wypełnieniu indywidualną zabudową jednorodzinną. Wydzielone obszary tworzą cztery wyraźne strefy, których zasięg określono $\mathrm{w}$ rozdz. 3. Ich zabudowa ma charakter skupień, a typ zabudowy, jej fizjonomia (domy jednorodzinne o wysokim standardzie) oraz okres powstania są przejawem „nowej” postsocjalistycznej suburbanizacji po $1990 \mathrm{r}$.

Na terenie Sławkowa zinwentaryzowano 380 domów jednorodzinnych powstałych w czasie ostatniego trzydziestolecia (w latach 1990-2018) (rys. 2). Ich liczba stanowi 18\% ogółu obecnej zabudowy mieszkaniowej w mieście. Zdecydowana większość nowej zabudowy ma charakter domów jednorodzinnych, wolnostojących wybudowanych indywidualnie (375 domów). W zabudowie deweloperskiej występuje natomiast jedynie pięć budynków (osiedle Leśna Polana). Połowa zabudowy

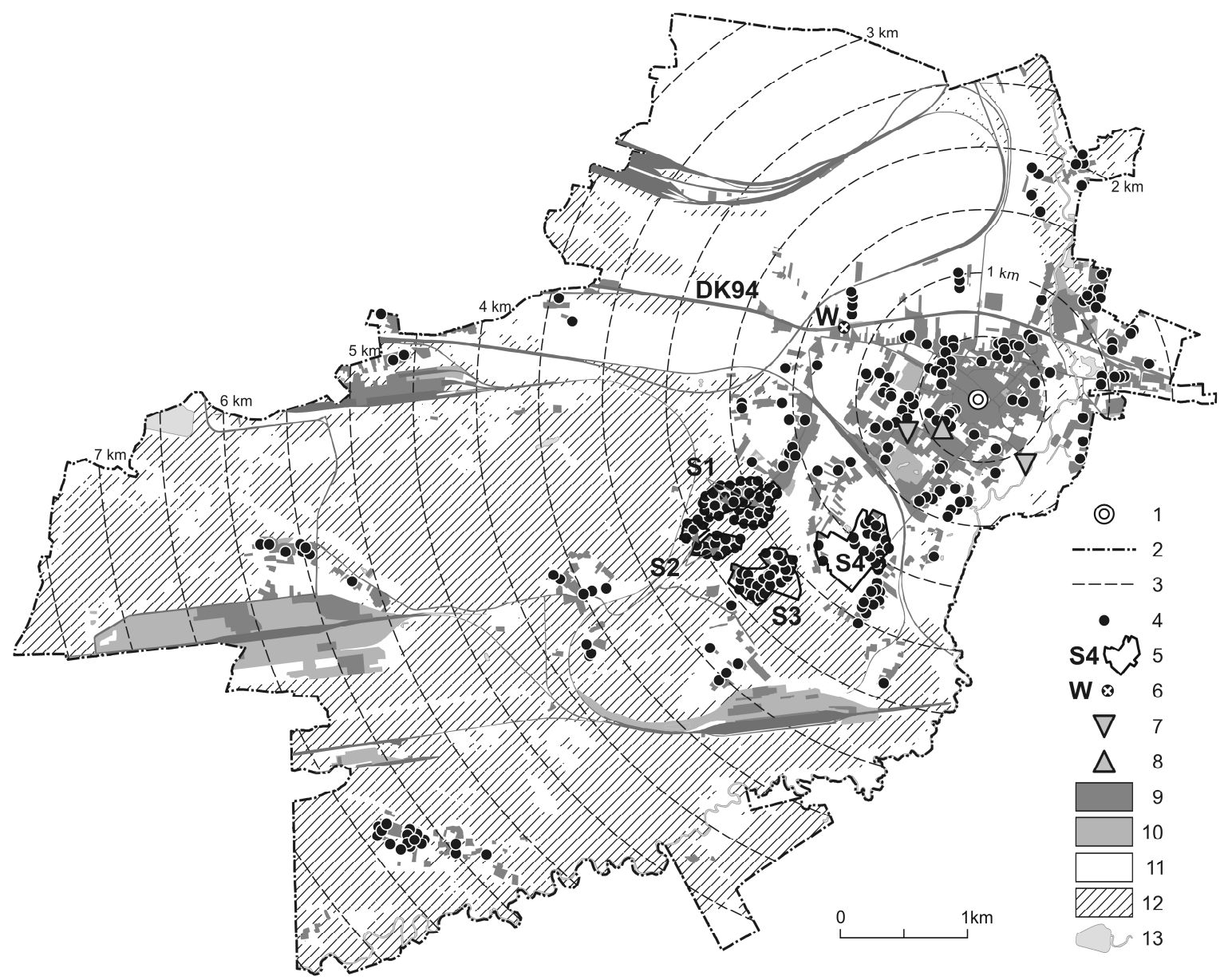

Rys. 2. Nowe inwestycje mieszkaniowe po 1990 r. na obszarze Sławkowa na tle użytkowania terenu

Objaśnienia: 1 - centrum miasta, 2 - granica miasta, 3 - ekwidystanty $500 \mathrm{~m}$ od centrum miasta, 4 - nowe inwestycje mieszkaniowe (domy jednorodzinne), 5 - obszar i symbol strefy badawczej, 6 - węzeł drogowy, główny wjazd na drogę DK94, 7 - szkoły podstawowe (SP), 8 - obiekty podstawowej opieki zdrowotnej (POZ), 9 - obszary zurbanizowane, 10 - pozostałe tereny zainwestowane, 11 - tereny roślinności trawiastej/upraw rolnych, 12 - tereny lasów, 13 - tereny wód Źródło: opracowanie własne na podstawie inwentaryzacji urbanistycznej oraz bazy BDOT 
jednorodzinnej powstałej w Sławkowie po $1990 \mathrm{r}$. jest zlokalizowana we wskazanych $\mathrm{w}$ rozdz. 3 czterech strefach osadniczych, położonych w odległości od 1,5 do 2,5 km od centrum miasta (tab. 1).

Tab. 1. Charakterystyka przestrzenna domów jednorodzinnych powstałych w latach 1990-2018 w badanych strefach osadniczych Sławkowa

\begin{tabular}{|l|c|c|c|c|c|}
\hline \multirow{2}{*}{ Wyszczególnienie } & \multicolumn{4}{|c|}{ Strefa } & \multirow{2}{*}{ Ogółem } \\
\cline { 2 - 5 } & 1. & 2. & 3. & 4. & ('średnia) \\
\hline $\begin{array}{l}\text { Powierzchnia strefy } \\
\text { (w km²) }\end{array}$ & 0,14 & 0,08 & 0,15 & 0,22 & 0,59 \\
\hline $\begin{array}{l}\text { Odległość strefy od } \\
\text { centrum miasta (w km) }\end{array}$ & 2,06 & 2,46 & 2,2 & 1,56 & $2,07^{*}$ \\
\hline $\begin{array}{l}\text { Liczba nowych domów } \\
\text { (ogółem) }\end{array}$ & 94 & 31 & 37 & 28 & 190 \\
\hline $\begin{array}{c}\text { - w tym w zabudowie } \\
\text { indywidualnej }\end{array}$ & 94 & 31 & 37 & 23 & 185 \\
\hline $\begin{array}{c}\text { - w tym w zabudowie } \\
\text { deweloperskiej }\end{array}$ & 0 & 0 & 0 & 5 & 5 \\
\hline $\begin{array}{l}\text { Wskaźnik intensywności } \\
\text { zabudowy (domy/km }{ }^{2} \text { ) }\end{array}$ & 671 & 388 & 247 & 127 & 322 \\
\hline
\end{tabular}

Źródło: opracowanie własne.

Specyfikę lokalizacji domów jednorodzinnych powstałych po $1990 \mathrm{r}$. w Sławkowie ukazuje szczegółowa analiza dotycząca ich rozmieszczenia względem: najważniejszych punktów miasta (jego centrum oraz węzła drogowego, umożliwiającego włączenie się do ruchu na drodze DK94), usług podstawowych oraz zabudowy sprzed 1990 r. (rys. 3). Odległości te zostały zmierzone za pomocą odległości euklidesowej, czyli w linii prostej, a nie wzdłuż sieci drogowej. W przypadku podstawowych usług publicznych wybrano jedynie te o najniższym stopniu centralizacji, do których dostęp powinien być najłatwiejszy. Do analizy wskazano: jedną przychodnię podstawowej opieki zdrowotnej (POZ) i trzy szkoły podstawowe (SP). Pominięto natomiast apteki, które są zlokalizowane w zabudowie otaczającej rynek (odległość ta sama, którą wykazano w badaniu dostępności śródmieścia).

Analiza rozmieszczenia wszystkich nowych lokalizacji zabudowy mieszkaniowej (domów jednorodzinnych) w Sławkowie względem obiektów podstawowej opieki zdrowotnej i szkół podstawowych wskazuje na ich bardzo duże zróżnicowanie przestrzenne. $Z$ punktu widzenia pieszego $\mathrm{w}$ większości przypadków odległości te są zbyt duże (wynoszą powyżej $1 \mathrm{~km}$, a maksymalnie osiągają wartość nawet $5 \mathrm{~km}$ ) (rys. 3A).

Szczegółowa analiza dotycząca wyłącznie wskazanych czterech stref suburbialnych dowodzi, że powstałe w nich domy charakteryzują się względnie

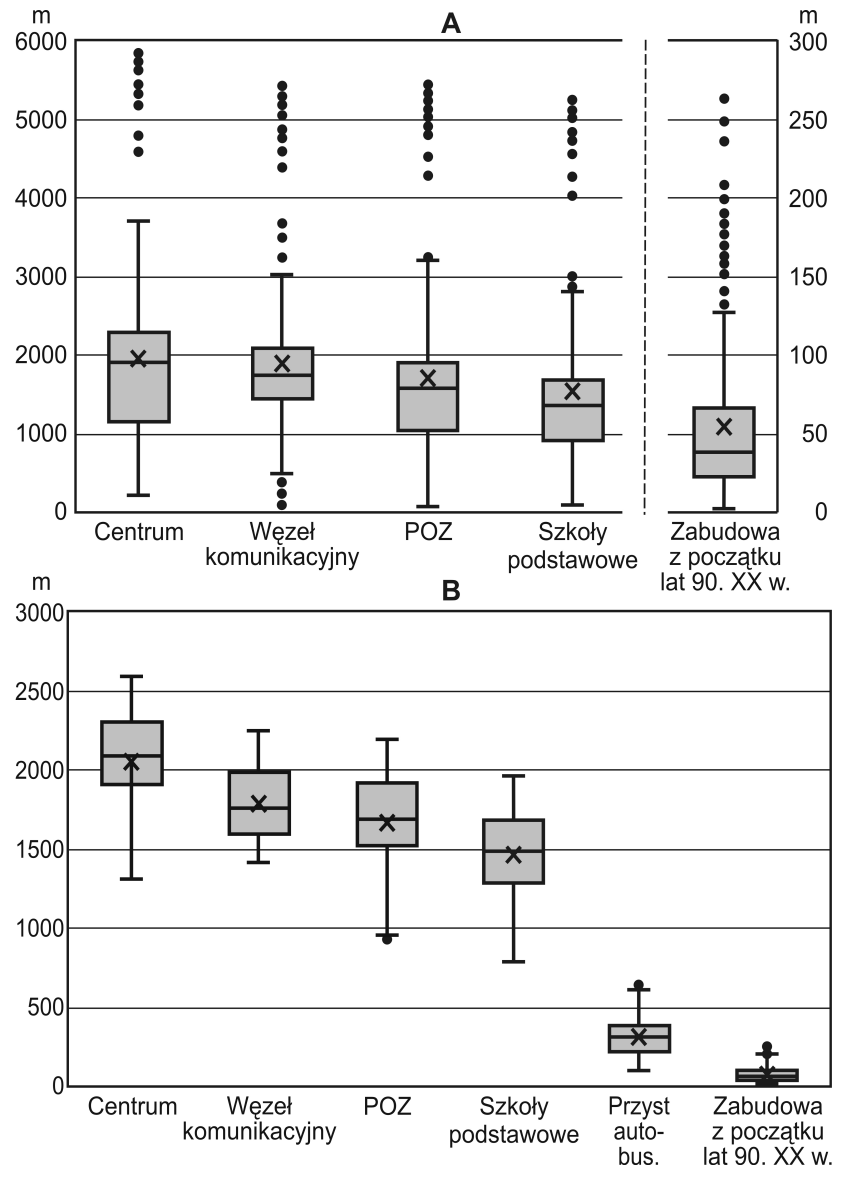

Rys. 3. Odległość nowo powstałych (w latach 1990-2018) domów jednorodzinnych w (A) Sławkowie (ogółem) i (B) w strefach: 1., 2., 3., 4. względem najważniejszych dla mieszkańców miejsc $\mathbf{w}$ mieście Źródło: opracowanie własne

dobrą dostępnością pieszą z punktu POZ i szkoły podstawowej (jednak $\mathrm{w}$ wielu przypadkach nadal nieumożliwiającą dobrą dostępność pieszą).

Odległość do budynków z początku lat 1990. nie przekracza $265 \mathrm{~m}$, co świadczy o rozwoju w tych strefach zabudowy stanowiącej kontynuację, a nie izolację.

Bardzo dobrym dostępem odznaczają się przystanki autobusowe. Ich odległość od omawianej zabudowy mieszkaniowej waha się między 88 i $303 \mathrm{~m}$ (por. rys. 3B). Niestety częstotliwość kursów autobusów jest zróżnicowana (od 5 kursów na dobę w strefie 4 . do $26 \mathrm{w}$ strefach 1 . i 2.). $Z$ badanych stref można dotrzeć do centrum Sławkowa liniami nr 949, 959, a także 49, którą można dostać się bezpośrednio do centrum Dąbrowy Górniczej. Czas przejazdu w godzinach porannych ze strefy 1 . do centrum Dąbrowy Górniczej wynosi 47 minut.

Oczywiście najszybszym środkiem transportu dla mieszkańców stref suburbialnych jest samochód osobowy, który pozwala na dotarcie m.in. do 

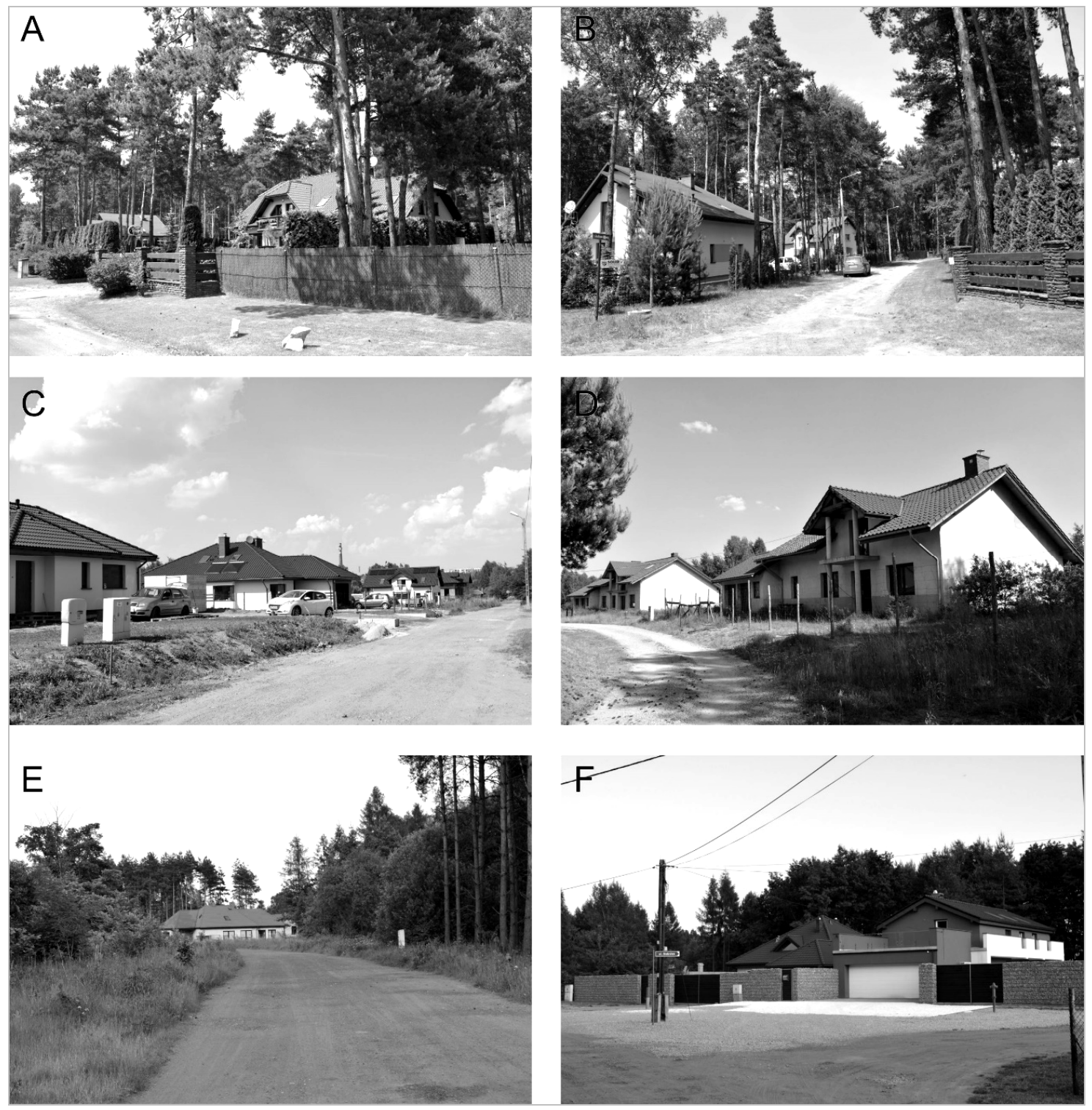

Fot. 1 A-F. Przykłady nowo powstałej zabudowy mieszkaniowej jednorodzinnej na obszarze Sławkowa Źródło: T. Spórna (2016 r.)

centrum Katowic w zaledwie 30 min. Ten środek transportu preferuje $96,5 \%$ mieszańców badanych stref.

Zabudowa jednorodzinna $\mathrm{z}$ uwagi na fakt, że jest przede wszystkim indywidualna ( $\mathrm{z}$ wyjątkiem jednego osiedla deweloperskiego Leśna Polana) jest zróżnicowana fizjonomicznie (por. fot. 1A-F). W większości dominują budynki średniej wielkości $\left(100-150 \mathrm{~m}^{2}\right)$, położone w bliskim sąsiedztwie terenów zielonych.

Przykładem powstania nowej zabudowy mieszkaniowej w Sławkowie jest osiedle Korzeniec, zlokalizowane w strefie 1., której obszar został poddany silnemu wylesieniu (skąd pewnie wzięła się jego nazwa Korzeniec) (por. fot. 2).

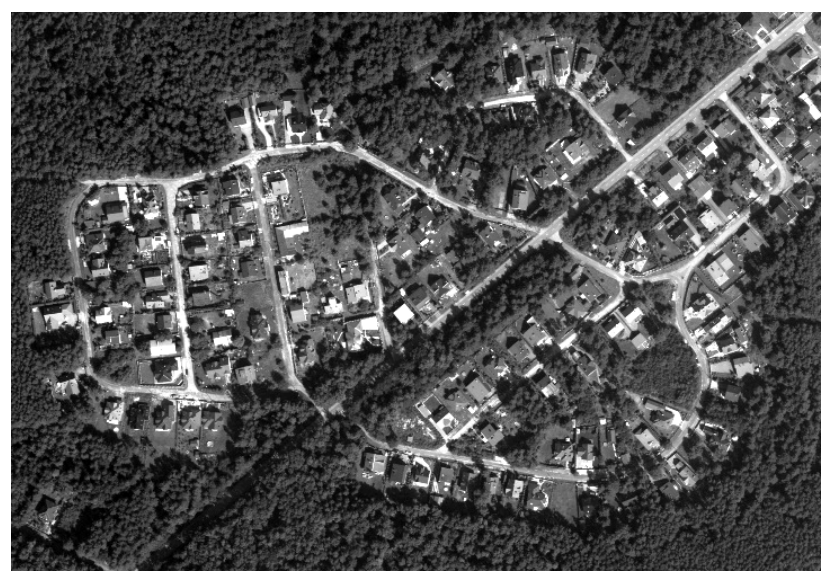

Fot. 2. Nowa zabudowa mieszkaniowa z lat 1990-2018 w osiedlu Korzeniec w Sławkowie Źródło: geoportal.gov.pl (2015 r.) 


\subsection{ZMIANY DEMOGRAFICZNE W MIEŚCIE JAKO PRZEJAW SUBURBANIZACJI}

Podstawowym przejawem rozpoczętego po $1990 \mathrm{r}$. procesu suburbanizacji w Slawkowie był wzrost liczby mieszkańców miasta (najsilniejszy w szczególności od 2001 r.). Pozytywna tendencja zmian zaludnienia Sławkowa była związana z poprawą sytuacji ekonomicznej miasta, planowaniem przestrzennym ukierunkowanym na rozwój urbanizacyjny oraz ze wzrostem zamożności mieszkańców ( $w$ tym potencjalnych migrantów z miast sąsiednich). Odzwierciedla się to $\mathrm{w}$ systematycznym wzroście zaludnienia miasta od 2001 r., kiedy odnotowano 6,65 tys. osób, do 2018 r., w którym liczba mieszkańców wynosiła już 7,04 tys. w (rys. 4).

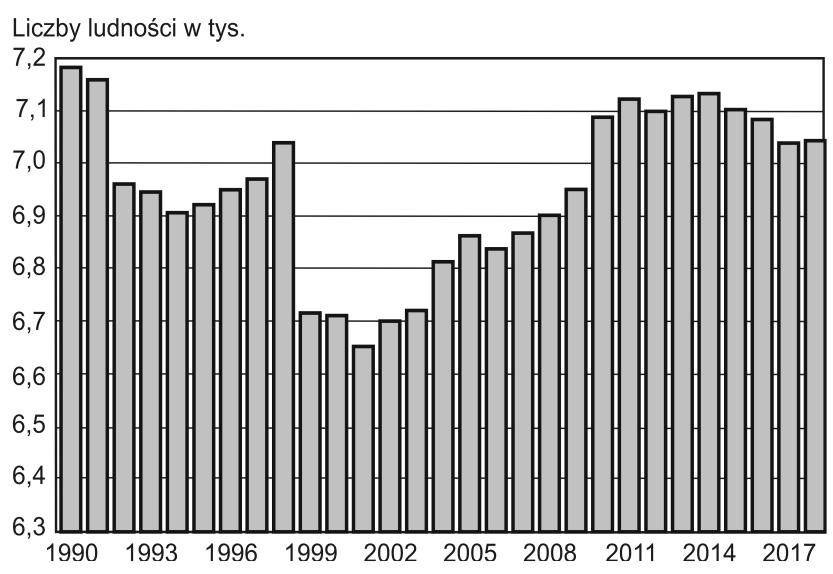

Rys. 4. Zmiany w liczbie ludności Sławkowa w latach 1990-2018 Źródło: opracowanie własne na podstawie

Rocznik statystyczny ... $(1992,1993,1994,1995)$ oraz BDL GUS

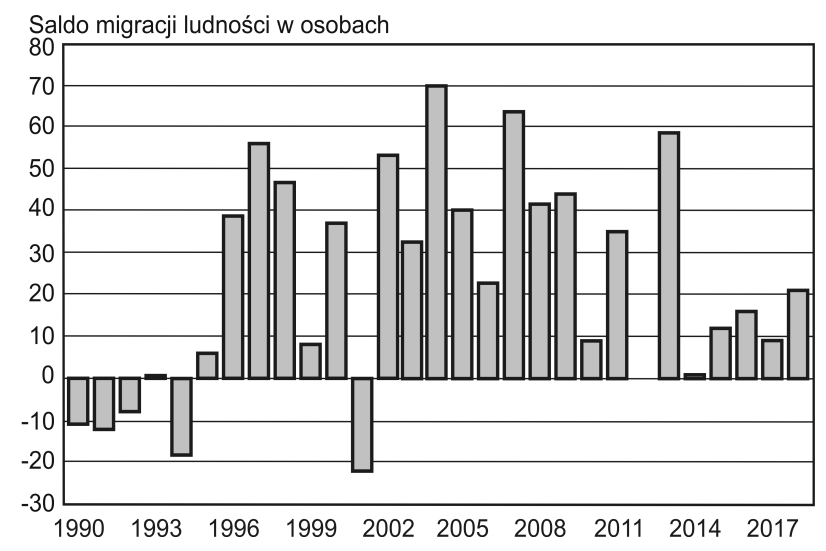

Rys. 5. Saldo migracji dla Sławkowa w latach 1990-2018 Źródło: opracowanie własne na podstawie Rocznik statystyczny... $(1992,1993,1994,1995)$ oraz BDL GUS

Kluczową składową wzrostu liczby ludności Sławkowa był napływ migracyjny, który od $1993 \mathrm{r}$. przyjmował wartości dodanie (z wyjątkiem 1994 i 2001 r.) (rys. 5). W latach 1995-2018 sumaryczne saldo migracji (wewnętrznych i zagranicznych) dla miasta wynosiło 702 osoby. W analizowanym okresie miasto charakteryzowało się przede wszystkim dodatnim bilansem migracji z miastami (718 osób) oraz ujemnym z gminami wiejskimi (-28 osób). W latach 2002-2018 najwięcej osób do Sławkowa przybyło z Dąbrowy Górniczej, Sosnowca i Katowic (Baza Demografia GUS).

Oczywiście zmiany zaludnienia Sławkowa w ujęciu przestrzennym były nierównomierne. Przede wszystkim dużą dynamikę zaludnienia odnotowywano na terenach objętych procesem suburbanizacji. Tylko w okresie 2004-2014 r. wzrost zaludnienia $\mathrm{w}$ badanych czterech strefach miasta wyniósł $91 \% 5$.

\subsection{CHARAKTERYSTYKA LUDNOŚCI STREF SUBURBIALNYCH ORAZ MOTYWY MIGRACJI DO NICH}

Charakterystyka społeczno-ekonomiczna mieszkańców stref suburbialnych oraz określenie głównych motywów ich zamieszkania w Sławkowie nastąpiło na podstawie wyników wywiadów pogłębionych (tab. 2 i 3). Przeprowadzono je w 2017 r. z przedstawicielami 20 gospodarstw domowych. Badaniami objęto $10,5 \%$ gospodarstw domowych $\mathrm{w}$ badanych czterech strefach, co pozwoliło na zebranie informacji od 66 mieszkańców.

Wśród mieszkańców stref suburbialnych przeważają osoby $\mathrm{w}$ wieku średnim (w wieku produkcyjnym, $68 \%$ ), dobrze wykształcone (50\% to osoby $\mathrm{z}$ wykształceniem wyższym). Potwierdziło to wcześniejsze przypuszczenia, że do stref suburbialnych migrują osoby, które założyły niedawno rodzinę, są dobrze wykształcone oraz bardziej zamożne.

Interesujące było poznanie pochodzenia nowych mieszkańców Sławkowa (stref suburbialnych) oraz motywów zarówno opuszczenia dotychczasowego miejsca zamieszkania, jak i wyboru nowego. Mieszkańcy poddanych badaniu stref pochodzą przede wszystkim z gmin bezpośrednio sąsiadujących ze Sławkowem, stanowiąc 70\%wszystkich tu przybyłych. Głównymi deklarowanymi miastami były Dąbrowa Górnicza (50\%) i Sosnowiec (20\%). Kolejnym wskazaniem jest sama gmina Sławków (15\%) oraz inne gminy spoza bezpośredniego otoczenia Sławkowa (15\%). Nowi mieszkańcy badanych stref miasta zamieszkiwali wcześniej głównie osiedla blokowe $z$ lat 70 . i 80 . XX w. $(80 \%)$, natomiast wła- 
ściciele zabudowy jednorodzinnej $\mathrm{w}$ poprzednim miejscu zamieszkania stanowili 15\% (tab. 2).

Tab. 2. Charakterystyka zabudowy stref podmiejskich Sławkowa oraz społeczno-demograficzna ich mieszkańców

\begin{tabular}{|c|c|c|c|c|}
\hline \multicolumn{5}{|c|}{$\begin{array}{c}\text { Charakterystyka przestrzenna budynku }(\mathrm{N}=20) \\
\text { (\% odpowiedzi) }\end{array}$} \\
\hline \multicolumn{4}{|c|}{ Dom jednorodzinny (wolnostojący) } & 100 \\
\hline \multicolumn{4}{|c|}{ Dom wybudowany indywidualnie } & 100 \\
\hline \multicolumn{4}{|c|}{ Powierzchnia użytkowa domu $151-200 \mathrm{~m}^{2}$} & 55 \\
\hline \multicolumn{5}{|c|}{ Struktura społeczno-demograficzna mieszkańcówa $(\%)$} \\
\hline \multirow{2}{*}{ Płeć } & \multicolumn{4}{|c|}{ Wiek $(\mathrm{N}=66)$} \\
\hline & $0-17$ & $18-44$ & $45-64$ & $65<$ \\
\hline Mężczyźni & 13,6 & 21,2 & 12,1 & 3,0 \\
\hline Kobiety & 10,6 & 27,3 & 7,7 & 4,5 \\
\hline $\begin{array}{l}\text { Wykształcenie } \\
(\mathrm{N}=50)\end{array}$ & wyższe & średnie & $\begin{array}{l}\text { zasadnicze } \\
\text { zawodowe }\end{array}$ & $\begin{array}{l}\text { podstawo- } \\
\text { we i gim- } \\
\text { nazjum }\end{array}$ \\
\hline Mężczyźni & 22,0 & 22,0 & 0,0 & 0,0 \\
\hline Kobiety & 28,0 & 28,0 & 0,0 & 0,0 \\
\hline \multicolumn{5}{|c|}{ Dojazdy do pracy $(\mathrm{N}=29)(\%$ odpowiedzi) } \\
\hline \multicolumn{4}{|c|}{ Ta sama gmina (Sławków) } & 17,2 \\
\hline \multicolumn{4}{|c|}{ Gmina sąsiadująca ze Sławkowem } & 37,9 \\
\hline \multicolumn{4}{|c|}{ Inna gmina } & 41,5 \\
\hline \multicolumn{4}{|l|}{ Zagranica } & 3,4 \\
\hline \multicolumn{5}{|c|}{ Środek transportu (\% odpowiedzi) } \\
\hline \multicolumn{4}{|c|}{ Własny samochód } & 96,5 \\
\hline \multicolumn{5}{|c|}{ Deklarowany czas dojazdu do pracy $(\mathrm{N}=29)(\%$ odpowiedzi) } \\
\hline \multicolumn{4}{|c|}{ Do $15 \mathrm{~min}$} & 24,2 \\
\hline \multicolumn{4}{|l|}{$16-30 \mathrm{~min}$} & 55,2 \\
\hline \multicolumn{4}{|l|}{$31-45 \mathrm{~min}$} & 13,8 \\
\hline \multicolumn{4}{|l|}{$46-60 \mathrm{~min}$} & 3,4 \\
\hline \multicolumn{4}{|c|}{$60 \mathrm{~min}$ i więcej } & 3,4 \\
\hline \multicolumn{5}{|c|}{$\begin{array}{c}\text { Poprzednie miejsce zamieszkania }(\mathrm{N}=20) \\
(\% \text { odpowiedzi) }\end{array}$} \\
\hline \multicolumn{4}{|c|}{ Ta sama gmina (Sławków) } & 15 \\
\hline \multicolumn{4}{|c|}{ Gmina sąsiadująca ze Sławkowem } & 70 \\
\hline \multicolumn{4}{|c|}{ Inna gmina woj. śląskiego } & 5 \\
\hline \multicolumn{4}{|c|}{ Inna gmina } & 10 \\
\hline \multicolumn{5}{|c|}{$\begin{array}{c}\text { Typ zabudowy poprzedniego zamieszkania }(\mathrm{N}=20) \\
(\% \text { odpowiedzi) }\end{array}$} \\
\hline \multicolumn{4}{|c|}{ Mieszkanie w bloku (sprzed 1990 r.) } & 80 \\
\hline \multicolumn{4}{|c|}{ Mieszkanie w kamienicy } & 5 \\
\hline \multicolumn{4}{|c|}{ Mieszkanie w bloku (wybudowane po 1990 r.) } & 0 \\
\hline Dom jednorodz & nny & & & 15 \\
\hline
\end{tabular}

Objaśnienia: a dane dotyczące wykształcenia według wieku obejmują też osoby uczące się.

Źródło: opracowanie własne.

Do głównych przyczyn opuszczenia dotychczasowego miejsca zamieszkania można zaliczyć marzenie o zamieszkaniu $\mathrm{w}$ domu jednorodzinnym $(35,9 \%)$ oraz bezpośrednio z tym związana chęć polepszenia jakości życia (23,1\%). Co ciekawe, wśród głównych motywów rzadko (tylko 5,1\% odpowiedzi) wymieniono zły stan środowiska przyrodniczego $\mathrm{w}$ poprzednim miejscu zamieszkania (tab. 3).
Tab. 3. Motywy oraz ocena zamieszkania w strefach podmiejskich Sławkowa

\begin{tabular}{|l|c|}
\hline \multicolumn{2}{|c|}{ Przyczyny opuszczenia poprzedniego miejsca zamieszkania } \\
$(\mathrm{N}=39)^{\mathrm{a}}$ (\% odpowiedzi)
\end{tabular}

Objaśnienia: a możliwość wielokrotnego wyboru odpowiedzi. Źródło: opracowanie własne.

Czynnikami, które zadecydowały o wyborze zamieszkania $\mathrm{w}$ sławkowskich suburbiach były przede wszystkim poszukiwanie spokojnej okolicy $(22,4 \%)$ i walory przyrodnicze $(20,7 \%)$. Koresponduje to ze szczegółową lokalizacją zabudowy, tj. na terenach otoczonych lasami, w oddaleniu od głównych dróg i śródmieścia miasta. Do kolejnych powodów wyboru Sławkowa zaliczono atrakcyjne ceny działek budowlanych $(12,2 \%)$ oraz poczucie bezpieczeństwa (12,1\%) (tab. 3).

Zapytani o spełnienie oczekiwań przez nowe miejsce zamieszkania respondenci z badanych stref dobrze ocenili liczbę i stan otaczających ich terenów zielonych, poczucie zachowania intymności zamieszkania oraz swojego bezpieczeństwa (tab. 3). 
Ocenili natomiast najniżej dostęp do ścieżek rowerowych i stan infrastruktury drogowej, a przede wszystkim dróg dojazdowych do ich posiadłości.

Pomimo dobrej dostępności do przystanków autobusowych mieszkańcy stref podmiejskich preferują własny samochód jako główny środek transportu (96,5\% odpowiedzi). Dojeżdżają nim do pracy, nie tylko do gmin z bezpośredniego otoczenia Sławkowa, ale także do odleglejszych ośrodków - Katowic, Chorzowa, Tychów czy też Krakowa.

\subsection{PRZYCZYNY POWSTANIA STREF NOWEGO OSADNICTWA (SUBURBANIZACJI) W SŁAWKOWIE}

\subsubsection{POLITYKA INWESTYCYJNA (PLANISTYCZNA) SAMORZĄDU MIASTA}

Główną przyczyną rozwoju zabudowy jednorodzinnej na obszarze Sławkowa była polityka władz gminnych ukierunkowana na rozwój nowej zabudowy mieszkaniowej. Bezpośrednią podstawą jej kreowania były uchwalone w latach 1991-2012 miejscowe plany zagospodarowania przestrzennego (por. bip.slawkow.pl/bipkod/019/013). Zapisy planów umożliwiły parcelację terenów użytkowanych dotychczas rolniczo lub terenów śródleśnych i leśnych oraz przeznaczenie ich pod funkcję mieszkaniową (zabudowę jednorodzinną). Były to przede wszystkim tereny wchodzące w skład „osiedli południowych", które obejmują badane strefy (1., 2., 3. i 4.). Ważnym dokumentem w kreowaniu zmian przestrzennych w gminie było uchwalone w 1998 r. Studium uwarunkowań i kierunków zagospodarowania gminy Sławków. Podlegało ono wielokrotnym aktualizacjom. Obowiązująca wersja Studium została uchwalona w 2019 r. Podtrzymuje ona dotychczasowy kierunek rozwoju przestrzennego miasta, oparty na zagospodarowaniu terenów wcześniej wyznaczonych pod zabudowę mieszkaniową (jednorodzinną).

Politykę inwestycyjną samorządu miasta dobrze obrazują słowa burmistrza Sławkowa, Rafała Adamczyka (2011b, s. 167):

Położenie miasta względem aglomeracji górnośląskiej oraz jego unikalna atmosfera są atrakcyjne dla jej mieszkańców, którzy ze względu na stale zwiększającą się uciążliwość mieszkania w dużych miastach poszukują dla siebie spokojnych i komunikacyjnie wyciszonych osiedli o podwyższonym (willowym lub rezydencjonalnym) standardzie. Samorząd miasta, dysponując odpowiednimi terenami pod zabudowę mieszkaniową, od kilkunastu lat prowadzi działania w kierunku rozwoju kameralnych osiedli jednorodzinnych Hrubieszowska i Stawki, optymalnie nasyconych zielenia, dla swoich dotychczasowych mieszkańców oraz mieszkańców aglomeracji górnośląskiej.

\subsubsection{POŁOŻENIE GEOGRAFICZNE GMINY}

Istotnym czynnikiem rozwoju nowych osiedli mieszkaniowych w Sławkowie jest jego atrakcyjne położenie geograficzne. Obszar miasta jest atrakcyjny do zamieszkania przede wszystkim dla mieszkańców sąsiadujących ośrodków (Dąbrowy Górniczej, Sosnowca, Bukowna, Olkusza), a nawet oddalonych o $30 \mathrm{~km}$ Katowic. Dobre skomunikowanie drogowe Sławkowa z dużymi miastami konurbacji katowickiej przyczyniło się do licznych migracji $\mathrm{z}$ nich. Przykładowo, zarówno podróż autem z centrum Dąbrowy Górniczej oraz Olkusza do centrum Sławkowa zajmuje 16 minut, z centrum Sosnowca 19, a Katowic 26.

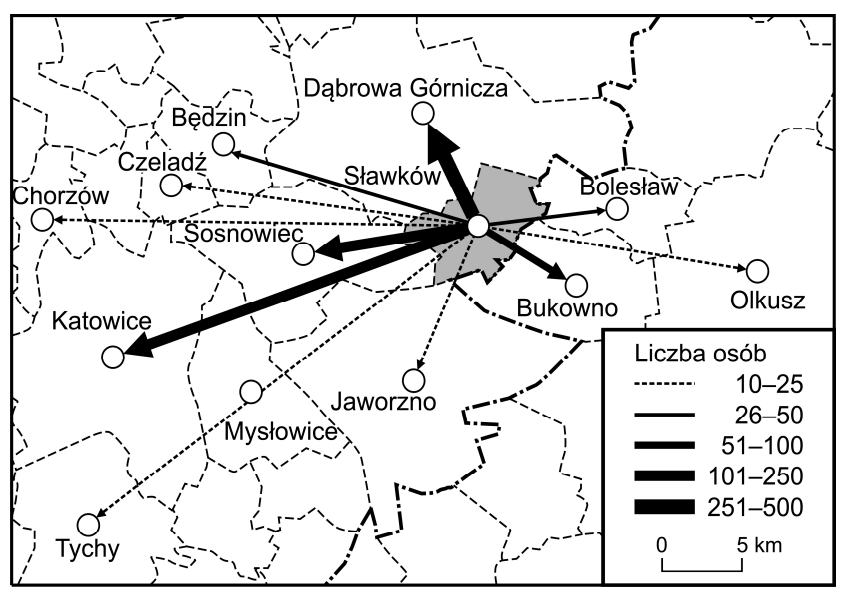

Rys. 6. Dojazdy do pracy mieszkańców Sławkowa w 2011 r. (dojazdy powyżej 9 osób)

Źródło: opracowanie własne na podstawie Dojazdy..

(2014)

Dobra dostępność komunikacyjna Sławkowa, w szczególności w kierunkach: Katowice-Sosnowiec -Sławków, Dąbrowa Górnicza - Sławków oraz Sławków-Bukowno odzwierciedla się w licznych dojazdach do pracy mieszkańców miasta (rys. 6). Potwierdzają to dane za 2011 r., kiedy wartość salda przyjazdów i wyjazdów do pracy dla miasta Sławkowa była ujemna i wyniosła -801 osób. Najsilniejsze powiązania $\mathrm{w}$ tym aspekcie wykazuje Sławków z miastami: Dąbrowa Górnicza (441 osób dojeżdżających do pracy), Katowice (207) i Sosnowiec (157).

Położenie miasta w strefie otaczającej rdzeń konurbacji katowickiej odzwierciedla się również 
w niższych, atrakcyjnych cenach działek budowlanych. W Sławkowie na początku 2017 r. ich wartość była zdecydowanie niższa np. od strefy suburbialnej $\mathrm{w}$ południowych Katowicach (ceny za $1 \mathrm{~m}^{2}$ powyżej $250 \mathrm{zl}$ ) oraz konkurencyjna do wartości działek w Dąbrowie Górniczej. Analizując oferty sprzedaży działek budowlanych w Sławkowie $^{6}$, zamieszczonych na portalu otodom.pl (2017 r., 33 oferty), stwierdzono, że ich średnia cena wynosiła $97,6 \mathrm{zl} / \mathrm{m}^{2}$, natomiast mediana - 95,4 zl/ m²; kwartyl dolny - 76,8 zl/m², a kwartyl górny $-110,0 \mathrm{zl} / \mathrm{m}^{2}$. Ceny te są konkurencyjne także w stosunku do innych terenów konurbacji, w tym wiejskich, takich jak: Bobrowniki oraz Ożarowice (por. Dyszy, 2015).

\section{PODSUMOWANIE}

Zinwentaryzowana nowo powstała (w latach 19902018) zabudowa mieszkaniowa w Sławkowie ze względu na charakter fizjonomiczny (domy jednorodzinne) oraz lokalizację (obszar podmiejski zarówno dla centrum miasta Slawkowa, jak i miast rdzenia konurbacji) ma charakter suburbii. Zabudowa ta stanowi interesujący przykład procesu suburbanizacji w policentrycznej aglomeracji miejskiej - tj. konurbacji katowickiej. Zachodzi w jej strefie zewnętrznej, na pograniczu dwóch województw i jest jednym $z$ wielu przykładów procesów suburbanizacji w konurbacji katowickiej (por. m.in. Petryszyn, Zuzańska-Żyśko, 2005; Runge, 2011; Spórna, Dragan, 2013; Zuzańska-Żyśko, Pytel, Koman, 2016; Spórna, 2018). Wpisuje się ona w ogólnopolskie trendy dekoncentracji przestrzennej dużych ośrodków miejskich i związany z tym proces rozwoju zabudowy jednorodzinnej na obszarze gmin stanowiących ich otoczenie (Lisowski, Grochowski, 2008; Zborowski, Raźniak, 2013).

Nowi mieszkańcy przy wyborze Sławkowa na miejsce osiedlenia kierują się przede wszystkim lokalizacją (dobry dostęp komunikacyjny do głównych miast rdzenia konurbacji katowickiej, spokojna i cicha okolica) oraz bliskością terenów zieleni. Motywy te są bardzo podobne do tych, jakie obserwowane są $\mathrm{w}$ przypadku migracji do innych stref podmiejskich w Polce (Kajdanek, 2012; Mantey, 2011; Źróbek-Różańska, Źróbek-Sokolnik, Dynowski, 2017).

Specyfika procesu suburbanizacji na obszarze Sławkowa polega na tym, że proces ten stanowi przemyślaną politykę przestrzenną i gospodarczą władz miejskich (Adamczyk, 2011b; Studium..., 2019). Jest nastawiona na wykreowanie $\mathrm{w}$ przestrzeni konurbacji katowickiej stref suburbialnych, przyciągających młodych zamożnych mieszkańców. Przestrzennie proces ten przybiera formę suburbanizacji „wyspowej" na terenach zielonych, w bezpośrednim sąsiedztwie terenów leśnych. Specyfika przestrzenna tego zjawiska odróżnia je od większości stref nowej zabudowy jednorodzinnej w konurbacji katowickiej, powstających głównie na terenach otwartych, porolniczych. Ma ona także charakter suburbanizacji „wewnętrznej”, zachodzącej w granicach miasta, w tym przypadku malego miasta.

Niewątpliwie badania rozwoju stref nowej zabudowy mieszkaniowej w Sławkowie, jak i na terenie innych małych miast oraz gmin wiejskich konurbacji katowickiej, wymagają dalszych badań. Przede wszystkim w kontekście koncepcji zrównoważonego rozwoju obszarów miejskich, jak również rosnącego chaosu przestrzennego w Polsce i jego negatywnych skutków (Śleszyński, Makowski, Kowalewski, 2018; Śleszyński, Stępniak, Mazurek, 2018).

\section{PRZYPISY}

${ }^{1}$ Praca powstała $\mathrm{w}$ wyniku realizacji projektu badawczego o nr DEC-2014/13/N/HS4/03575 finansowanego ze środków Narodowego Centrum Nauki.

${ }^{2} \mathrm{~W}$ wielu przypadkach $\mathrm{w}$ procesie suburbanizacji rezydencjonalnej, zabudowie jednorodzinnej towarzyszy także nowa zabudowa wielorodzinna niska.

3 Obecnie pod nazwą Linia Hutnicza Szerokotorowa. Linia kolejowa łączy Sławków z krajami Dalekiego Wschodu (m.in. Rosją i Chinami, w tym miastami Władywostok, Xi'an i Szanghaj).

${ }^{4} \mathrm{~W}$ delimitacji konurbacji katowickiej zaproponowanej przez Krzysztofika (2007) Sławków znajduje się w jej strefie wewnętrznej.

5 Obliczenia własne na podstawie zgeokodowanej bazy PESEL dla lat 2004 i 2014. Wzrost liczby mieszkańców z 242 do 463 (MSWiA).

${ }^{6} \mathrm{Na}$ początku 2020 r. ceny najatrakcyjniejszych działek budowlanych wynoszą około $180 \mathrm{zt} / \mathrm{m}^{2}$. Nadal jednak są one konkurencyjne $\mathrm{z}$ cenami działek budowlanych $\mathrm{z}$ obszaru innych miast konurbacji.

\section{BIBLIOGRAFIA}

Adamczyk, R. (2011a). Rewitalizacja małych miast strefy zewnętrznej aglomeracji górnośląskiej. W: K. Heffner, T. Marszał (red.), Rewitalizacja, gentryfikacja i problemy rozwoju małych miast. Studia. KPZK PAN, 136, s. 43-54.

Adamczyk, R. (2011b). Sławków - brama aglomeracji górnośląskiej na wschód?. W: T. Marszał, B. Bartosiewicz (red.), Kie- 
runki $i$ uwarunkowania rozwoju matych miast $z$ perspektywy 20 lat transformacji. Studium przypadków (s. 151-170). Wyd. Uniwersytetu Łódzkiego, Łódź.

Dyszy, M. (2015). Budownictwo jako czynnik dynamizujący rozwój strefy podmiejskiej na przykładzie wybranych gmin w otoczeniu aglomeracji górnośląskiej. Prace Komisji Geografii Przemystu Polskiego Towarzystwa Geograficznego, 29 (2), s. 113-122.

Dziewoński, K., Kiełczewska-Zaleska, M., Kosiński, L., Kostrowicki, J., Leszczycki, S. (red.) (1957). Studia geograficzne nad aktywizacją małych miast. Prace Geograficzne IG PAN, 9.

Gibas, P. (2011). Struktura użytkowania ziemi w małych miastach otoczenia aglomeracji śląskiej. W: B. Bartosiewicz, T. Marszał (red.), Struktura przestrzenna matych miast z perspektywy 20 lat transformacji (s. 91-107). Łódź: Wyd. Uniwersytetu Łódzkiego.

Gołąb-Korzeniowska, M. (2008). Małe miasta Krakowskiego Obszaru Metropolitalnego jako zaplecze mieszkalne Krakowa. W: K. Heffner, T. Marszał (red.), Ośrodki lokalne w strefie oddziaływania wielkich miast. Biuletyn KPZK PAN, 238, s. 50-61.

Heffner, K. (2008). Zmiany roli i kierunków rozwoju małych miast w strefach metropolitalnych. W: K. Heffner, T. Marszał (red.), Ośrodki lokalne $\mathrm{w}$ strefie oddziaływania wielkich miast. Biuletyn KPZK PAN, 238, s. 6-23.

Heffner, K., Marszal, T. (red.) (2005). Problemy rozwoju małych miast $\mathrm{w}$ wymiarze lokalnym i regionalnym. Biuletyn. KPZK PAN, 220.

Heffner, K., Marszał, T. (red.) (2007). Małe miasta w obszarach metropolitalnych. Biuletyn. KPZK PAN, 232.

Heffner, K., Marszał, T. (red.) (2011). Rewitalizacja, gentryfikacja i problemy rozwoju małych miast. Studia KPZK PAN, 136.

Jażdżewska, I. (red.) (2009). Strefa podmiejska i małe miasta w okresie transformacji. XXII Konwersatorium Wiedzy o Mieście. Cz. 2. Łódź: Wyd. Uniwersytetu Łódzkiego.

Jażewicz, I. (2008). Małe miasta w strefie ekspansji aglomeracji gdańskiej. W: K. Heffner, T. Marszał (red.), Ośrodki lokalne w strefie oddziaływania wielkich miast. Biuletyn KPZK PAN, 238 , s. 39-49.

Kajdanek, K. (2012). Suburbanizacja po polsku. Kraków: Zakład Wydawniczy "Nomos".

Kiryk, F. (red.) (2001). Dzieje Stawkowa. Kraków: Sukcesja.

Klasik, A. (2019, Nowa urbanizacja regionu miejskiego. W: K. Gasidło, A. Klasik, B. Muster (red.), Nowa urbanizacja na starym podtożu (s. 9-24). Katowice: Wyd. Uniwersytetu Ekonomicznego w Katowicach.

Konecka-Szydłowska, B., Matykowski, R. (2005). Procesy urbanizacji w Wielkopolsce oraz w strefie podmiejskiej Poznania. W: Jażdżewska I., (red.). Wspótczesne procesy urbanizacji i ich skutki. XVIII Konwersatorium Wiedzy o Mieście (s. 153-161). Łódź: Wyd. Uniwersytetu Łódzkiego.

Korzeniak, G. (2014). Małe i średnie miasta w policentrycznym rozwoju Polski. Kraków: Instytut Rozwoju Miast.

Krzysztofik, R. (2007). Struktura przestrzenno-administracyjna konurbacji katowickiej. Czasopismo Geograficzne, 78, s. 288-304.

Krzysztofik, R., Kantor-Pietraga, I., Runge, A., Spórna, T. (2017). Is the suburbanisation stage always important in the transformation of large urban agglomerations? The case of the Katowice conurbation. Geographia Polonica, 90 (2), s. 71-85.

Kurek, S., Wójtowicz, M., Gałka, J. (2020). Population growth in functional urban areas. W: S. Kurek, M. Wójtowicz, J. Gałka (red.). Functional urban areas in Poland: Demographic trends and migration patterns. Cham: Springer International Publishing, s. 33-50.
Kwiatek-Sołtys, A. (2011). Małe miasta w polskiej literaturze geograficznej ostatniego dwudziestolecia. W: B. Bartosiewicz, T. Marszał (red.). Kierunki i uwarunkowania rozwoju matych miast z perspektywy 20 lat transformacji. Łódź, Wyd. Uniwersytetu Łódzkiego, s. 9-56.

Lisowski, A., Grochowski, M. (2008). Procesy suburbanizacji. Uwarunkowania, formy i konsekwencje. W: K. Saganowski, M. Zagrzejewska-Fiedorowicz, P. Żuber (red.), Ekspertyzy do Koncepcji przestrzennego zagospodarowania kraju 2008-2033. T. I. Warszawa: Ministerstwo Rozwoju Regionalnego, s. 217280.

Lorens, P. (2005). Suburbanizacja w procesie rozwoju miasta postsocjalistycznego. W: P. Lorens (red.), Problem suburbanizacji. Biblioteka Urbanisty, 7, s. 33-44.

Maleszka, H., Kazak, J., Szewrański, S. (2016). Małe miasto a obszary wiejskie w strefie suburbialnej - studium przypadku gminy Oborniki Śląskie. Studia Ekonomiczne. Zeszyty Naukowe Uniwersytetu Ekonomicznego w Katowicach, 279, s. 25-36.

Mantey, D. (2011). Żywiołowość lokalizacji osiedli mieszkaniowych na terenach wiejskich obszaru metropolitalnego Warszawy. Warszawa: Wydział Geografii i Studiów Regionalnych UW.

Matuszczyk, Z. (2016). Sławków - odzyskanie praw miejskich [1984]. W: Stawków. Historia. Kultura. Ludzie, 1, s. 29-38.

Milewska-Osiecka, K. (2016). Budownictwo mieszkaniowe i sytuacja demograficzna $w$ małych miastach i na ich obszarach wiejskich (przykład województwa łódzkiego). Studia Ekonomiczne. Zeszyty Nauk Uniwersytetu Ekonomicznego w Katowicach, 276, s. 150-161.

Ogrodowczyk, A. (2011). Polityka przestrzenna a rozwój budownictwa mieszkaniowego po 1990 roku na przykładzie małych miast w województwie łódzkim. Acta Universitatis Lodziensis. Folia Geographica Socio-Oeconomica, 11, s. 167-186.

Opania, S. (2016). Studium struktury przestrzennej małego miasta. W: B. Bartosiewicz (red.), Tendencje w rozwoju gospodarczym i przestrzennym małych miast w Polsce. Space -Society-Economy, 17, s. 49-66.

Orłowski, S. (2001). Po drugiej wojnie światowej. W: F. Kiryk (red.), Dzieje Stawkowa (s. 427-566). Kraków: Secesja.

Petryszyn, J., Zuzańska-Żyśko, E. (2005). Rozmieszczenie nowych inwestycji mieszkaniowych w aglomeracji katowickiej. W: I. Jażdżewska (red.), Wspótczesne procesy urbanizacji i ich skutki. XVIII Konserwatorium Wiedzy o Mieście (s. 361-370). Łódź: Wyd. Uniwersytetu Łódzkiego.

Polko, A. (2010). Funkcja mieszkaniowa małych miast w strefie oddziaływania aglomeracji górnośląskiej. W: K. Heffner, A. Polko (red.), Transformacja funkcji miejskich w ośrodkach lokalnych (s. 299-310). Katowice: Wyd. Akademii Ekonomicznej w Katowicach.

Runge, J. (2011). Społeczno-gospodarcze oraz przestrzenne przejawy suburbanizacji w województwie śląskim. W: J. Słodczyk (red.). Procesy suburbanizacji w wybranych miastach Polski. Studia Miejskie, 3, s. 55-66.

Schmidt, S., Fina, S., Siedentop, S. (2015). Post-socialist sprawl: A cross-country comparison. European Planning Studies, 23 (7), s. $1357-1380$.

Spórna, T. (2012). Modele przemian urbanizacyjnych w województwie śląskim. Prace Wydziatu Nauk o Ziemi Uniwersytetu Śląskiego, 72.

Spórna, T. (2018). The suburbanisation process in a depopulation context in the Katowice conurbation, Poland. Environmental \& Socio-Economic Studies, 6 (1), s. 57-72.

Spórna, T., Dragan, W. (2013). Zmiany w zagospodarowaniu przestrzennym centralnej części Sosnowca w latach 19932012. Acta Geographica Silesiana, 13, s. 71-86. 
Stanilov, K., Sýkora, L. (red.) (2014). Confronting suburbanization: Urban decentralization in postsocialist Central and Eastern Europe, Wiley-Blackwell, Chichester.

Szaton, K. (2016). Znaczenie małych miast w kontekście rozwoju struktur ponadlokalnych na przykładzie aglomeracji górnośląskiej. W: B. Bartosiewicz (red.), Tendencje w rozwoju gospodarczym i przestrzennym matych miast w Polsce. Przestrzeń. Społeczeństwo. Gospodarka (s. 67-83). Wyd. Uniwersytetu Łódzkiego, Łódź.

Szymańska, D., Grzelak-Kostulska, E. (2005). Problematyka małych miast $\mathrm{w}$ Polsce $\mathrm{w}$ świetle literatury. Biuletyn KPZK PAN, 220, s. 21-36.

Śleszyński, P. (2006). Demograficzny wymiar procesów suburbanizacji w Polsce po 1989 roku. W: S. Kozłowski (red.), Żywiołowe rozprzestrzenianie się miast. Narastający problem aglomeracji miejskich w Polsce, Studia nad zrównoważonym rozwojem. T. II, Ekonomia i środowisko. Białystok-Lublin-Warszawa (s. 105-123).

Śleszyński, P., Markowski, T., Kowalewski, A. (red.) (2018). Studia nad chaosem przestrzennym, cz. 3. Synteza. Uwarunkowania, skutki i propozycje naprawy chaosu przestrzennego. Studia KPZK PAN, CLXXXII.

Śleszyński, P., Stępniak, M., Mazurek, D. (2018). Oszacowanie skutków presji inwestycyjnej i nadpodaży gruntów budowlanych w strefie podmiejskiej Warszawy na przykładzie gmin pasma zachodniego. Przeglad Geograficzny, 90 (2), s. 209-240.

Świdurska, A. (2008). Małe miasta a rozwój obszarów wiejskich w Poznańskim Obszarze Metropolitalnym. W: K. Heffner, T. Marszał (red.), Ośrodki lokalne w strefie oddziaływania wielkich miast. Biuletyn KPZK PAN, 238, s. 120-132.

Zborowski, A., Raźniak, P. (2013). Suburbanizacja rezydencjonalna w Polsce - ocena procesu. Studia Miejskie, 9, s. 37-50.

Zuzańska-Żyśko, E. (2001). Architektura krajobrazu małych miast województwa śląskiego. W: U. Myga-Piątek (red.), Krajobraz kulturowy - idee, problemy, wyzwania (s. 160-169). Sosnowiec: WNoZ UŚ, Oddział Katowicki PTG.

Zuzańska-Żyśko, E. (2006). Małe miasta w okresie transformacji. Studium w regionie śląskim. Katowice: Wyd. Śląsk.

Zuzańska-Żyśko, E. (2007). Małe miasta w strefie oddziaływania ośrodków regionalnych. W: K. Heffner, T. Marszał (red.). Małe miasta $\mathrm{w}$ obszarach metropolitalnych. Biuletyn KPZK PAN, 232, s. 62-78.

Zuzańska-Żyśko, E., Pytel, S., Koman, W. (2016). Suburbanization in postindustrial area. Case study of The Silesia Metropolitan Region. W: R. Efe, I. Cürebal, L. Lévai (red.), GeoMed 2016. 4th International Geography Symposium. Book of Proceedings. Kemer, Antalya (Turkey), s. 835-849.

Źróbek-Różańska, A., Źróbek-Sokolnik, A., Dynowski, P. (2017). Czy mieszkańcy miast preferują tereny cenne przyrodniczo pod budowę domu pod miastem? Studium strefy podmiejskiej Olsztyna. Prace Geograficzne, 149, s. 123-139.

\section{Dokumenty planistyczne}

Miejscowe plany zagospodarowania przestrzennego miasta Stawkowa, (2006 ze zm.). Sławków; bip.slawkow.pl/bipkod/019/013.

Strategia rozwoju miasta Stawkowa na lata 2014-2020. Aktualizacja, (2015). Sławków: Biuro Doradcze Altima s.c..

Studium uwarunkowań $i$ kierunków zagospodarowania przestrzennego miasta Stawkowa (1998). Sławków.

Studium uwarunkowań i kierunków zagospodarowania przestrzennego miasta Stawkowa (2003). Sławków.

Studium uwarunkowań $i$ kierunków zagospodarowania przestrzennego miasta Stawkowa (2008). Sławków.

Studium uwarunkowań $i$ kierunków zagospodarowania przestrzennego miasta Stawkowa (2011). Sławków: Alma Projekt.

Studium uwarunkowań $i$ kierunków zagospodarowania przestrzennego miasta Stawkowa (2019). Sławków: Alma Projekt.

\section{Materiały kartograficzne}

Baza danych obiektów topograficznych (BDOT 10k) (2013). Warszawa: Główny Urząd Geodezji i Kartografii.

Mapa topograficzna w skali 1 : $10000 \mathrm{w}$ układzie 1992 (1992). Arkusze: M-34-63-B-a-1; M-34-63-B-a-2; M-34-63-B-a-3; M-34-63B-a-4; M-34-63-B-b-1; M-34-63-B-b-3. Warszawa: Państwowe Przedsiębiorstwo Geodezyjno-Kartograficzne.

Ortofotomapa (2017). Warszawa: Główny Urząd Geodezji i Kartografii.

\section{Materiały statystyczne}

Bank Danych Lokalnych GUS [dane za lata 1995-2018]. Warszawa: GUS.

Baza Demografia, Arkusz 2g [dane za lata 2002 -2018]. Warszawa: GUS.

Baza PESEL, Warszawa: MSWiA.

Dojazdy do pracy. Narodowy Spis Powszechny Ludności i Mieszkań $(2011,2014)$. Warszawa - aneks - macierz dojazdów. Warszawa: GUS.

Rocznik statystyczny województwa katowickiego za rok: 1992, 1993, 1994, 1995 (1993-1996). Katowice: WUS.

\section{Źródła internetowe}

geoportal.gov.pl

geoportal.slawkow.pl

ORSIP (Otwarty Regionalny System Informacji Przestrzennej Województwa Śląskiego). Katowice: http:/ /www.orsip.pl otodom.pl targeo.pl

Artykuł wpłyną: 10 czerwca 2019 Zaakceptowano do druku: 19 października 2019 